\title{
The Development and Revelation of the World Soybean Industry
}

\section{Qiang-Ping GU}

Shcool of Economic and Management, Shenyang Agricultural University, Shenyang 110866, China; School of Accounting, Heilongjiang August First Land Reclamation University, Daqing, 163319, China

Jing ZHOU

Shcool of Economic and Management, Shenyang Agricultural University, Shenyang 110866, China

ABSTRACT: Utilizing the FAO data since1961, the article analyzed the development and changes in soybean industry of the world in the past 50years. And based on the analysis of the development in production and trade in soybean industry of the world, the article put forward the aspects the soybean industry in China should be reference, in the hope of promoting the development in soybean industry in China.

KEYWORD: soybean Industry; Production; Trade

\section{THE SOYBEAN PRODUCTION SITUATIONS OF THE WORLD}

In 2012, the world gross output of soybean is 262037600 tons. The four leading countries in soybean production are: American, Brazil, Argentina and China. The changes of soybean gross output and the proportion among the world gross out of America, Brazil, Argentina and China were different. Though the degrees of increase were different, there was a rising trend of different level of the gross output of the four countries. And from the point of proportion, Brazil and Argentina were on the rise, while America and China were on the decline.

The American soybean production has always been in the leading place, rising from 18468000 tons in 1961 to 82054800tons in 2012, with an increase of 3.4 times. Its proportion in the world gross output, however, has been decreasing, from $68.7 \%$ in 1961 to $32.42 \%$ in 2012 . And though China has been among the first four countries in production, the increasing speed is very slow, from 6210000tons in 1961 to 12800000 tons in 2012, increasing only 1.1 times. In addition, its proportion has been on the decrease, from $23.1 \%$ in 1961 to $5.06 \%$ in 2012 . In the 1960s, the soybean production in Brazil was relatively low, only tens of thousand tons, but its increase has been fast, and its production surpassed that of China in 1974(78765000 tons), coming second in the world. Its share in production initially climbed up slowly and then rose sharply (first from $1.01 \%$ in 1961 to $8.46 \%$ in 1973 , then from $14.96 \%$ in 1974 to $25.95 \%$ in 2012). The soybean production in Argentina has also enjoyed an fast increase, from 1000tons in 1961 to 51500000 tons in 2012, and its production surpassed China from 1998(18732200 tons), coming third in the world. Except obvious fluctuation in its proportion between 1989 and 1997, the other years has saw the increasing trend, reaching $20.34 \%$ in 2012.

It can be seen from the above analysis that the gradual decrease of Chinese soybean production proportion has mainly been affected by the constant increase in production share of Brazil and Argentina and has little to do with the changes in American soybean production and its share. For the past 50years, though American soybean production has been in the leading place and increased constantly, its share shows the tendency of decrease, so American soybean production and its share has little influence in Chinese soybean production share. While when Chinese soybean production share decreased, that of Brazil and Argentina has constantly climbed up: the sum of two countries' share was only $2 \%$, and increased to $46 \%$ in 2012 , even surpassing the sum of that of America and China-37\%.

\section{THE SOYBEAN EXPORT TRADE SITUATION OF THE WORLD}

Because soybean production is concentrating, limited only to few countries, while its consumption is global, so soybean has become one of the produce that enjoy high trade volume in the world market. Affected by the concentration of soybean production countries, the soybean export countries are correspondingly relatively concentrating. It can be seen from the world soybean export situation, 
America, Brazil and Argentina are the world's first three countries in exporting soybeans, with the soybean production accounting for $37.69 \%, 36.24 \%$ and $11.89 \%$ respectively. The soybean export of the three countries accounted for $85.82 \%$ of world's total share.

From the soybean export volume of the soybean export countries and their market share during the span from 1961 to 2011 , it can be seen that the soybean export volume of America, Brazil and Argentina are not only large but also show a tendency of growing. And compared with the three countries, Chinese export volume has been low. Seen from the share they accounted for respectively, that of America has been dropping, that of Brazil and Argentina have been basically on the rise, and that of China has been low.

The American soybean export volume has been in the leading place, leaving the other countries far behind. And from 1961 to 2011, the volume increased 8 times: from 3634200 tons to 34310500 tons. Its share in the world, however, has been decreasing, from $87.08 \%$ in 1961 to $37.69 \%$ in 2011 , dropping $49.39 \%$. American decrease in the share of soybean export was mainly caused by the increase in share of Brazil and Argentina. During the period, the soybean export volume increased from 73300 tons in 1961 to 32985600 tons in 2011, and its share increased from $1.76 \%$ to $36.24 \%$, with an increase of $34.48 \%$; and that of Argentina increased from $1.01 \%$ in 1961 to $11.89 \%$ in 2011 , with an increase of $11.89 \%$. The drop in share of American soybean export roughly amounts to the sum of increase in share of Brazil and Argentina added together. Within the 50years, the average share of Chinese export is $2.7 \%$, with $8.26 \%$ as the highest and $0.17 \%$ as the lowest. It can be seen that compared with the other main soybean production countries, Chinese soybean export share has been low.

\section{THE SOYBEAN IMPORT TRADE SITUATION OF THE WORLD}

Different from the concentration of soybean export, world soybean import is very discrete. China, Mexico, German, Spain, Netherland, Japan, Indonesia, Thailand, Turkey, Italy, South Korea, Egypt and Vietnam have become the leading 13 countries in soybean import.The import shares of 12 countries ranking 2 nd to 13 th range from $1 \%$ to $3.68 \%$, the total share of the countries other than the 13 countries is $14.28 \%$, which can show the discreteness in soybean import. While the share of China alone is $57.76 \%$, becoming the world's largest soybean import country.

Chinese soybean import share had been low until 1996, and even been zero before 1972. Since 1996, however, Chinese soybean import share has increasing rapidly, and reached $57.76 \%$ in 2011, exceeding more than half of the world's total, thus becoming the super country in soybean import.

\section{ANALYSIS OF THE PRODUCTION AND TRADE SITUATION OF SOYBEAN INDUSTRY}

\subsection{Production}

\subsubsection{America}

American soybean production and harvest area both rank first in the world. And the production per unit area is also among the world's leading countries. So it's the biggest country in soybean production in the world, which owes a lot to American government's support in soybean farming. Firstly, America established numerous agricultural cooperative societies, and developed soybean production through large-scale management, which was conducive to low cost and high production of soybean. Secondly, America has also set up various institutions to promote the development of soybean farming, such as Joint soybean Bureaus, American Soybean Associations, International Soybean Center, Soybean Protein Partnership Associations, Soybean Enzyme Production Center, Soybean Processors' Association, Soybean Food Associations, and Edible Protein Committees. Besides, the supporting policies such as American soybean planting loans, government's subsidiary, and support for the development projects have played a promoting role in the development of American soybean farming.

\subsubsection{Brazil and Argentina}

In 1970, the proportion of the soybean production of Brazil and Argentina added together was less than $4 \%$, while in 1980, 1990, 2000 an 2012, the proportion was respectively $24 \%, 28 \%, 32 \%$ and $46 \%$, rising perpendicularly. The rapid development of soybean production in Brazil and Argentina can be attributed to the following reasons: Firstly, the two countries are basically located in the temperate climate and the soil is fertile. So the soybean can easily grow and have high production at the same time of saving on fertilizer and lowering cost. Secondly, the two governments have been supporting soybean farming. For example, Brazilian government organized the soybean farmers of the country to form farm consortium, the purchase of production materials such as fertilizer and seeds will be in the charge of the consortium. The measure save the purchase cost and contributed to large-scale production of soybean of the same quality. The farm consortium is also in charge of raising money, establishing devices for transportation, storage and drying, providing relatively low-price service. Argentina has carried out the economic reform in 
1990s, implementing marketization of government and taking measures to reduce burdens from soybean industry, thus creating good external conditions for the development of soybean industry. Lastly, the two countries have increased investment in soybean research. The Brazilian scientific system centered on the government and its appropriate scientific orientation has played an important role in increasing soybean production per unit area and adapting to regions. At the same time, Brazil established national soybean center, providing technical guidance and support to soybean farmers and invested heavily in cultivating talents in soybean scientific research and developing new breeds. In order to save production cost on soybean, Argentina introduced zero tillage cultivation, and at the same time, adopted the new agricultural method of crop rotation used in other crops, thus greatly increased soybean production per unit area.

\subsection{Trade}

\subsubsection{America}

America organized the specialized institutions such as Overseas Agricultural Bureau of Agricultural Ministry to develop international market, mainly responsible for the overseas development of American produce. And American soybean association was established to promote soybean domestically and internationally. Domestically, soybean association mainly strengthens the communication with the trade of health care, food, fodder and medicine to develop new products and new market. Internationally, the agencies have been set up in different continents, mainly responsible for negotiating soybean business with soybean import and export countries. All these measures have guaranteed the steady increase of American soybean export.

\subsubsection{Brazil and Argentina}

Brazilian government has formulated the policy of trade liberalization or cancelled the regulations that hinder the trade of produce such as the tariffs and quotas, so that Brazilian produce could enter the international market more smoothly. In order to increase the competitiveness of soybean in the international market, Brazil has stipulated different production procedures and quality standard to adapt to the different market in Asia and Europe. At the same time, Brazilian government has supported soybean export trade financially, making the regulation that soybean export can be exempted from the $20 \%$ of the trade tax. Some states also set up special funds to prevent against natural disasters, providing free reparations to disaster-plagued farmers. Argentine government reduced or even cancelled export tax and fees on different kinds of examinations in the reform of port policies, thus reducing the cost of the trade in produce export and promoting the trade in it. Argentine government is also devoted to improving the external environment of soybean export, recommends international organizations to reduce the constraints that affect produce trade, and advises WTO to quicken its step to lower the tariffs.

\section{REVELATIONS OF THE DEVELOPMENT IN SOYBEAN PRODUCTION AND TRADE OF THE WORLD ON CHINA}

China is one of the main soybean consumption countries, and also used to be the big country in producing and exporting soybean. At present, however, by ranking fourth in production, it's the world's biggest import country, while its export comes after the tenth. Obviously, international status of soybean in China has been strikingly dropped. Rejuvenating soybean industry and improve the international competitiveness of soybean is the problem we are faced with. According to the above analysis of the situations in production and trade development of America, Brazil, Argentina and China, it's suggested that Chinese soybean industry should borrow the experience from the following aspects.

\subsection{To create an fair competition environment for soybean industry Trade}

To change the unfair competition environment in which the soybean industry in China has been monopolized by foreign capital, the macroregulation by the government is needed. In treating the foreign investment, the government must set strict licensing mechanism to exclude the foreign investments which are planning to undertake soybean crushing. At the legal level, the government should strengthen the legalization in economy, improving antitrust law, providing legal basis for preventing foreign investment monopolizing the soybean industry in our country. At the policy level, the government should reinforce guidance to the soybean enterprises in the country, relieve and avoid the vicious competition among the them and it should strongly support the big and medium sized soybean crushing enterprises, granting them favorite conditions in loans and taxes and providing particular support to the enterprises that have the potential to establish independent industrial chains.

\subsection{To increase the farmers' profit in planting soybeans}

Farmers are the principal part in soybean planting. And soybean industry would be meaningless without 
them. And in market economy, as the rational economic persons, farmers' choice in crops is mainly dependent on the profit. So the ways must be devised to increase the farmers' profit in soybean farming to promote their initiative in planting soybeans. Firstly, to increase the production per unit area of soybeans by improving and introducing new breeds and equipment and cultivating technologies and reducing cost. Secondly, to continue the policy of protecting the soybean price and strengthen and widen the protection range and enlarging the range in subsidies: increasing subsidy in promoting new technologies and investment subsidy in adapting agricultural structure, and subsidy in scientific research in reproducing the soybean seeds by the scientific institutions and colleges. Lastly, to guide the farmers to avoid the risks in soybean production and management, by joining agricultural insurance and utilizing future market.

\subsection{To increase the degree of farmer's rganization}

The soybean farmers should be guided to establish specialized soybean cooperative organizations, and the degree of farmer's organization be increased, to promote the scale farming, standardized production and industrialized management of soybeans, and to boost the construction by advantageous industry. Farmers should be encouraged to plant breeds of high quality, thus improving the production and quality for soybeans and increasing the market competitiveness of soybeans by planned and purposeful unifying cultivation and management.

\subsection{To strengthen soybean scientific research}

Firstly, the basic study of soybean production should be strengthened, including cultivating high quality and new breed and improving the traditional cultivating technologies. The promoting and applying system of the new soybean breed and cultivating technology should be established and perfected, enabling the scientific products to play their practical roles in a faster and better way. Secondly, the study in soybean processing should be strengthened, and the industrial process of soybean processing should be quickened. Simultaneously, the products containing bioactive constituents should be researched vigorously, such as soyprotein, soy asaponin and soy isoflavone, thus increasing the soybean's added value by developing the new products of soybean processing through scientific innovation.

\subsection{To reasonably control soybean import}

Currently, the soybean import in our country has been increasing steadily, and the dependence of soybean import is $80 \%$. The high dependency of soybean import does great harm to the safety of Chinese soybean industry. Therefore, domestic soybean's effective supply should be increased by enlarging the planting areas of soybeans, increasing soybean production per unit area and its soybean quality, and at the same time, soybean import should be reduced. In addition, the imported soybeans are transgenic, the effects of which on the health of human being and on the eco-environment are yet to be testified. So from the perspective of protecting eco-safety and the health of mankind, animal and plants, the inspection system of transgenic soybean should be established and perfected to control soybean import, and the quality of transgenic soybeans should be examined strictly, and import of transgenic soybeans with potential safety hazard should be banned.

\subsection{To protect the original production regions}

Heilongjiang Province is the main production area of soybeans in China, where the soybeans produced are free of pollution and non-transgenic, thus welcomed in the international market by the countries such as Japan and Korea. But with the import of large amount of transgenic soybeans, domestic nontransgenic soybean resources face great threat. It's advised that the department concerned in the government to thoroughly carry out Genetically modified product safety regulations and formulate the policies to protect the non-transgenic soybeans in our country to ensure the safety of quality breed resources and cultivate and expand the local breed resources.

\section{REFERENCES}

[1] Hao lan. Analysis on the Structural Changes in the World Soybean Market and China's Strategies. International trade issues2008(6):39-44

[2] Shengwen-Hou. The present situation and the trend of the world soybean production. Agriculture and technology2010(2):1-2

[3] Wubing-Liu. Agricultural products trade of China in 2012. The world's agricultural2013(6):147-150

[4] Yao Cheng. Using the experience of major soybean producing countries to promote the healthy development of soybean industry in China. Soybean science 2012(6):1013-1016 